\title{
'Substrate-Accelerated Death' of Aerobacter aerogenes
}

\author{
By R. E. STRANGE AND F. A. DARK \\ Microbiological Research Establishment, Porton, Wiltshire
}

(Received 6 November 1964)

\begin{abstract}
SUMMARY
'Substrate-accelerated death' (Postgate \& Hunter, 1963a, 1964) was observed with carbon-limited but not ammonium-, phosphate- or sulphatelimited Aerobacter aerogenes grown at $37^{\circ}$ in defined medium and starved at $37^{\circ}$ in aerated saline buffers containing the growth-limiting substrate. Carbon sources besides the one limiting growth increased the death-rate of starved mannitol-, glycerol-, galactose- and ribose-limited bacteria. Glycerol-accelerated death depended on the rate of oxidation of glycerol and the bacterial concentration; with bacteria fully adapted to glycerol, populations of less than $1-2 \times 10^{9}$ organisms $/ \mathrm{ml}$. died at a faster rate the denser the population and above this concentration the death-rate decreased with increasing bacterial concentration. Death was delayed when aerated bacterial suspensions containing glycerol were dialysed at $37^{\circ}$ against saline buffer containing the substrate. Bacteria-free filtrates, from populations dying in the presence of glycerol, accelerated the death of fresh bacteria to a greater extent than did glycerol alone. In contrast, bacteria-free filtrates from dense populations surviving in the presence of glycerol partially protected fresh bacteria exposed to glycerol. $\mathbf{M g}^{2+}$ abolished glycerol-accelerated death but not the lethal effect of filtrates from dying populations. Compared with its influence on glycerolaccelerated death, population density had much less influence on the death-rate of glycerol- or mannitol-limited organisms starved in the presence of glucose or mannitol. Irrespective of bacterial concentration, $\alpha$-ketoglutarate had no effect and pyruvate, citrate, malate, succinate and oxalacetate had less effect than glycerol on the death-rate of starved glycerol-limited bacteria.
\end{abstract}

\section{INTRODUCTION}

According to Postgate \& Hunter (1963 $a, b ; 1964)$, 'substrate-accelerated death' is a general phenomenon which occurs when starved bacteria are exposed to the substrate which limited their growth. Exceptions are the effects of magnesium ions and sulphate ions on magnesium- and sulphate-limited bacteria, respectively. Postgate \& Hunter mention certain considerations that emphasize the practical importance of their findings, for example when bacterial death occurs because of the presence of substrate during Warburg oxygen-uptake experiments and during investigations concerned with induction or repression of enzyme synthesis. Certain possible interpretations of the phenomenon were excluded by the authors but the mechanism is not understood and deserves attention. Our work in this connexion commenced with a formal repetition of their experiments with populations of Aerobacter aerogenes grown at $37^{\circ}$. With certain important exceptions, the results with carbon- and sulphate-limited bacteria agreed with those of Postgate \& Hunter but ammonium-accelerated death of ammonium-limited bacteria was not observed. 
Phosphate-accelerated death apparently occurred under their conditions but the lethal effect was found to be due, not to phosphate, but to other constituents in the suspending fluid. In view of the discrepancies and the effect our findings have on the concept of substrate-accelerated death as previously reported, we record a partly repetitive investigation of the phenomenon.

\section{METHODS}

Organism. Aerobacter aerogenes (NCTC 418) was used.

Media and cultural conditions. Organisms were grown at $37^{\circ}$ in a chemostat or in batch culture (Strange \& Shon, 1964). The chemostat, designed by Dr D. Herbert, was as described by Postgate \& Hunter (1962) except that the culture vessel held $250 \mathrm{ml}$. medium. All defined media contained salt mixture (Strange, Dark \& Ness, 1961) (5 ml./l.), carbon energy source (2-10 g./1.), disodium ethylenediaminetetraacetic acid (EDTA; 0.5 g./l.). Carbon-limiting medium contained (g./l.): $\mathrm{NaH}_{2} \mathrm{PO}_{4}$ $(0 \cdot 6),\left(\mathrm{NH}_{4}\right)_{2} \mathrm{HPO}_{4}(5 \cdot 95)$ and $\mathrm{K}_{2} \mathrm{SO}_{4}(1 \cdot 75)$. Phosphate-limiting medium contained (g./l.): $\mathrm{NaHCO}_{3}(0 \cdot 42), \mathrm{NH}_{4} \mathrm{HCO}_{3}(3 \cdot 55), \mathrm{K}_{2} \mathrm{SO}_{4}(1 \cdot 75), \mathrm{NaH}_{2} \mathrm{PO}_{4} \cdot 2 \mathrm{H}_{2} \mathrm{O}(0.0625$; $0.4 \mathrm{~mm}$ ), and the $\mathrm{pH}$ value of the culture was maintained at $6.8-7 \cdot 2$ by the addition of $\mathrm{CO}_{2}$ to the air supply. Sulphate-limiting medium contained (g./l.): $\mathrm{NaH}_{2} \mathrm{PO}_{4}$ (0.6), $\left(\mathrm{NH}_{4}\right)_{2} \mathrm{HPO}_{4}(5 \cdot 95), \mathrm{KCl}(0 \cdot 75), \mathrm{Na}_{2} \mathrm{SO}_{4}(0 \cdot 0044 ; 0.031 \mathrm{mM})$. Nitrogenlimiting medium (1) contained (g./l.): $\mathrm{NaH}_{2} \mathrm{PO}_{4} \quad(0 \cdot 6), \quad\left(\mathrm{NH}_{4}\right)_{2} \mathrm{HPO}_{4} \quad(0 \cdot 99$; $15 \mathrm{~mm}-\mathrm{N}), \mathrm{Na}_{2} \mathrm{HPO}_{4}(5 \cdot 3), \mathrm{K}_{2} \mathrm{SO}_{4}(1 \cdot 75)$; nitrogen-limiting medium (2) contained (g./l.): $\quad \mathrm{NaH}_{2} \mathrm{PO}_{4} \cdot 2 \mathrm{H}_{2} \mathrm{O}(1 \cdot 56), \quad \mathrm{K}_{2} \mathrm{HPO}_{4}(15 \cdot 7), \quad \mathrm{K}_{2} \mathrm{SO}_{4}(3 \cdot 5), \quad \mathrm{NH}_{4} \mathrm{Cl}$ $(0 \cdot 268 ; 5$ mм-N). P-, S- and N-limiting (2) media were similar to those used by Postgate \& Hunter (1962) but did not contain added trace amounts of $\mathrm{CuCl}_{2}$, $\mathrm{CoCl}_{2}, \mathrm{H}_{3} \mathrm{BO}_{3}$ and $\mathrm{Na}_{2} \mathrm{MoO}_{4}$. In trial runs, the addition of these substances to media had no significant effect on the yield of bacteria, their viability (98-100\%) or their survival in the absence or presence of substrates.

Continuous cultures were run for a maximum period of 4 weeks and in no case was there a detectable change in morphology or colonial appearance of the organism. Starting inocula consisted of fully grown batch cultures of the organism in the same media (100 ml.) seeded with colonies from a stock nutrient agar plate, and shaken at $37^{\circ}$ for $16-20 \mathrm{hr}$. Equilibrium in a chemostat was reached after 24-48 hr. Samples of cultures were examined daily for $\mathrm{pH}$ value, turbidity, bacterial dry weight, viable count and viability by slide culture.

Viability determinations. Viable counts were made on 3 or 5 Douglas's digest broth agar plates for each determination as previously described (Strange et al. 1961). The \% viable bacteria in a suspension was determined microscopically with dark ground illumination after slide culture on the rich medium described by Postgate, Crumpton \& Hunter (1961) except that glucose $(0 \cdot 2 \%$, w/v) replaced glycerol.

Starvation. Bacteria were separated from the culture (1 vol.) and washed in the appropriate saline buffer (2-4 vol.) by centrifugation. The bacterial pellet was gently rinsed and resuspended in saline buffer $(0 \cdot 1-1 \cdot 0$ vol.). Measured volumes of washed suspension were added to saline buffer with and without substrates (final vol., 5 or $10 \mathrm{ml}$.) usually in test tubes $\left(6 \times \frac{5}{8}\right.$ in. $)$ at $37^{\circ} \pm 0.1^{\circ}$, and aerated with sterile washed air through Pasteur pipettes. When experiments lasted longer than 
$6 \mathrm{hr}$, similar suspensions were agitated in Erlenmeyer flasks (50 ml.) on a reciprocal shaker at $37^{\circ} \pm 1^{\circ}$. Saline buffers with and without substrates were sterilized by filtration through well-washed sterile membrane filters (grade A.P.; Oxo Ltd.).

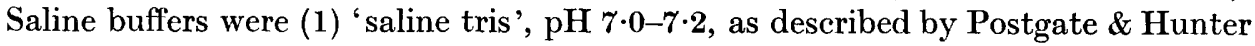
(1962) but without EDTA; when EDTA $(0 \cdot 3 \mathrm{~mm})$ was added this is noted in Results. Saline tris had extremely poor buffering capacity but was used for the purpose of comparing results with those of Postgate \& Hunter $(1962,1963 a, 1964)$. (2) 'Saline phosphate' $\mathrm{pH} 6.5$ usually contained $\mathrm{NaCl}(0.11 \mathrm{M})$ and $\mathrm{K}_{2} \mathrm{HPO}_{4}+$ $\mathrm{KH}_{2} \mathrm{PO}_{4}\left(0 \cdot 02 \mathrm{M}-\mathrm{PO}_{4}\right)$; in some experiments appropriate $\mathrm{Na}$ buffer salts replaced $\mathbf{K}$ salts and, in others, potassium phosphates were increased to increase buffering capacity, and $\mathrm{NaCl}$ was proportionally decreased. The $\mathrm{pH}$ values of solutions of substrates or EDTA were adjusted when necessary before addition to saline buffers.

Materials. Water used for media was passed twice through a mixed-bed ionexchange resin (Amberlite MB-1; British Drug Houses Ltd.). Saline buffers were prepared daily with fresh glass-distilled water. Mannitol and galactose were obtained from George T. Gurr Ltd.; all other chemicals were from British Drug Houses Ltd. and, except for ribose, of Analytical Reagent grade.

Analytical methods. Protein, RNA, DNA, keto acids and bacterial dry weight were determined as previously described (Strange et al. 1961; Strange \& Shon, 1964). Total purine pentose in hot $\mathrm{HClO}_{4}$-extracts was determined by the method of Millitzer (1946). Total carbohydrate excluding pentose was determined with a modified anthrone reaction based on the method of Trevelyan \& Harrison (1952), with glucose as the standard (P. J. Phipps, personal communication). Ultraviolet (u.v.) absorption spectra were obtained with an Optica recording grating spectrophotometer (model CF 4DR; Optica United Kingdom Ltd., Gateshead on Tyne 11), with a $1 \mathrm{~cm}$. light path.

Cell-free filtrates of bacterial suspensions were obtained by centrifugation followed by filtration of the supernatant fluids through well-washed membrane filters.

\section{RESULTS}

\section{Properties of cultures and compositions of bacteria}

Culture yields (mg. dry wt. bacteria/mg. limiting element) in chemostats and analyses of certain bacterial constituents are shown in Table 1. Comparison of these data with similar data of Postgate \& Hunter (1962; their Table 4) for Aerobacter aerogenes (variant) growing at $40^{\circ}$ shows that yields were similar but chemical compositions differed, sometimes markedly, at $37^{\circ}$ and $40^{\circ}$. For example, $\mathrm{N}$-limited organisms grown at $37^{\circ}$, at dilution rates of $0 \cdot 18-0 \cdot 61$, contained $14-24 \%$ polysaccharide as glucose, whereas those grown at $40^{\circ}$ at a dilution rate of $0 \cdot 24$ contained $\mathbf{3 . 8} \%$, i.e. little more than C-limited bacteria grown at either temperature. P- and $\mathrm{S}$-limited bacteria grown at similar dilution rates at $37^{\circ}$ also contained considerably more polysaccharide than C-limited organisms (Table 1 ), but at $40^{\circ}$, at lower dilution rates, they contained only slightly more. 


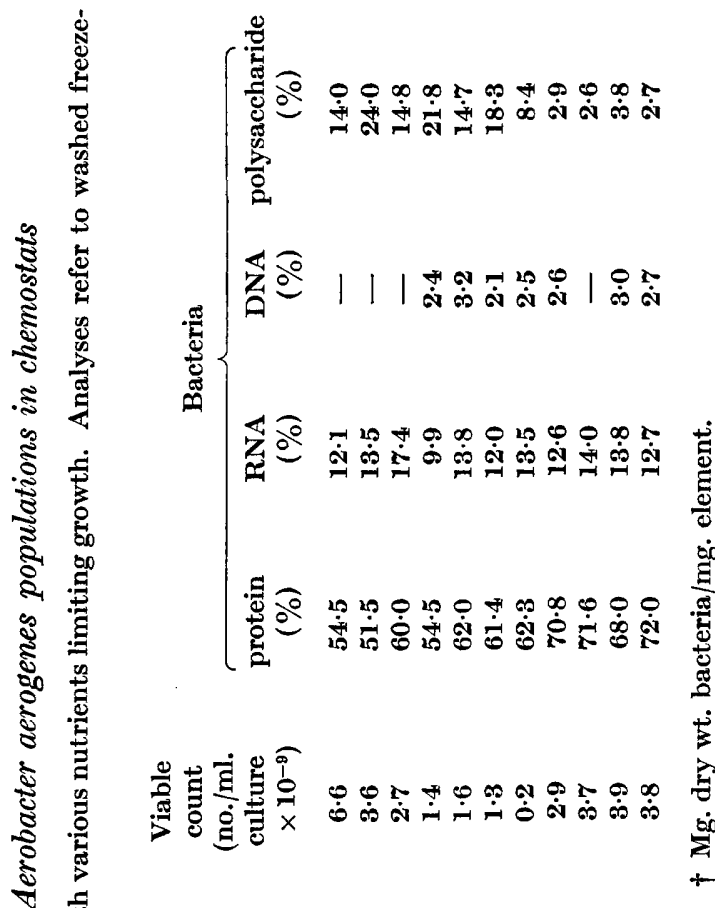

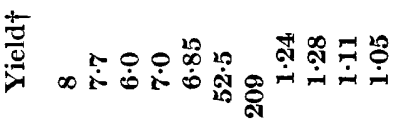

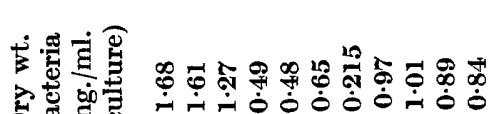

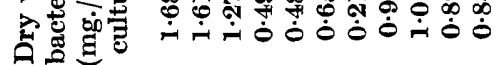

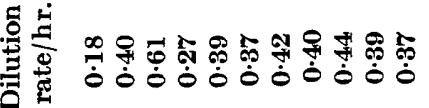




\section{Effect of growth substrates on starved bacteria \\ Nitrogen-limited bacteria}

Fourteen samples of bacteria from three chemostats, one containing N-limiting medium (1) with mannitol, and the others $\mathrm{N}$-limiting medium (2) with glycerol (Table 1), were washed and starved at $37^{\circ}$ in aerated saline tris $(\mathrm{pH} 7 \cdot 0)$ or saline phosphate $(\mathrm{pH} 6.5)$ with or without $\mathrm{NH}_{4} \mathrm{Cl}(10-25 \mathrm{~mm})$. In no test was the survival significantly affected by $\mathrm{NH}_{4} \mathrm{Cl}$ (Table 2 ). Similarly, bacteria harvested during the late-exponential and stationary phases of growth from $\mathrm{N}$-limited batch cultures,

Table 2. Effect of various substrates and EDTA on the death-rate of starved, Nitrogen-limited Aerobacter aerogenes

Bacteria, grown in $\mathrm{N}$-limiting medium (2) (dilution rate, $0 \cdot 27 / \mathrm{hr}$ ) were washed and starved (at equiv. $8 \mu \mathrm{g}$. dry wt. bacteria/ml.) at $37^{\circ}$ in aerated saline tris $(\mathrm{pH} 7 \cdot 0$ ) or saline phosphate (pH 6.5), with or without addition, in shaken flasks. Viabilities (slide culture) are average of results for duplicate tests.

Diluent

Saline phosphate

Saline tris
Additives

Nil
Glycerol (10 mm)
Mannitol (10 mM)
Glucose (10 mm)
$\mathrm{NH}_{4} \mathrm{Cl}(10 \mathrm{~mm})$
$\mathrm{NH}_{4} \mathrm{Cl}(25 \mathrm{~mm})$
EDTA $(0 \cdot 3 \mathrm{~mm})$

Nil

Glycerol (10 mM)

$\mathrm{NH}_{4} \mathrm{Cl}(20 \mathrm{~mm})$

EDTA $(0 \cdot 3 \mathrm{~mm})$

EDTA $(0 \cdot 3 \mathrm{~mm})+$ $\mathrm{NH}_{4} \mathrm{Cl}(20 \mathrm{~mm})$

EDTA (0.3 mM)+

$\mathrm{KH}_{2} \mathrm{PO}_{4}(10 \mathrm{mM})$

EDTA $(0 \cdot 3 \mathrm{mM})+$

$\mathrm{KCl}(10 \mathrm{~mm})$

\begin{tabular}{lcr}
\multicolumn{3}{c}{ Time (hr) } \\
$\overbrace{2}$\begin{tabular}{c}
20 \\
\multicolumn{2}{c}{ Viability $(\%)$}
\end{tabular} \\
98 & 98 & 98 \\
99 & 70 & 69 \\
98 & 89 & 65 \\
98 & 63 & 70 \\
99 & 98 & 97 \\
98 & 99 & 93 \\
97 & 51 & $*$ \\
99 & 96 & 98 \\
98 & 96 & 94 \\
98 & 97 & 97 \\
99 & 73 & 57 \\
99 & 97 & 87 \\
98 & 50 & 44 \\
97 & 50 & 43
\end{tabular}

* Bacterial lysis occurred in the suspensions.

and starved in saline phosphate, were unaffected by $\mathrm{NH}_{4} \mathrm{Cl}(4 \cdot 5-45 \mathrm{~mm})$. These results were diametrically opposed to those of Postgate \& Hunter $(1963 a, 1964)$ and an explanation for this discrepancy was sought. Postgate \& Hunter (1962) found that EDTA $(0.32 \mathrm{~mm})$ improved the survival of Aerobacter aerogenes in saline tris at $40^{\circ}$ and for this reason they added EDTA routinely. In the present work, numerous tests with bacteria growth-limited by $\mathrm{N}, \mathrm{P}, \mathrm{S}$ or $\mathrm{C}$ showed that EDTA was slightly toxic in saline tris at $37^{\circ}$. With $\mathrm{N}$-limited bacteria, viabilities after starvation for $22 \mathrm{hr}$ in saline tris with and without EDTA $(0.3 \mathrm{~mm})$ were $60-85 \%$, and $95-99 \%$, respectively. Since the addition of $\mathrm{NH}_{4} \mathrm{Cl}(10-25 \mathrm{~mm})$ to saline tris + EDTA actually improved survival, the discrepancy was not due to the absence of EDTA from our tests. Another possibility was that the bacterial concentrations used in our respective tests were sufficiently different to influence 
survival in the presence of $\mathrm{NH}_{4} \mathrm{Cl}$. However, changing the concentration from equiv. 10 to $300 \mu \mathrm{g}$. dry wt. bacteria $/ \mathrm{ml}$. had no effect on the survival of starved $\mathrm{N}$-limited bacteria exposed to $\mathrm{NH}_{4} \mathrm{Cl}(20 \mathrm{~mm})$.

In saline phosphate, glucose and mannitol $(10 \mathrm{~mm})$ increased the death rate of $\mathrm{N}$-limited bacteria grown in the presence of either glycerol or mannitol as the carbon source (Table 2). Glycerol (10 mM) increased the death-rate of $\mathrm{N}$-limited organisms grown in medium containing glycerol (Table 2) and the lethal effect increased with bacterial concentration up to equiv. $500 \mu \mathrm{g}$. dry wt./ml. In saline tris + EDTA $(0.3 \mathrm{mM}), \mathrm{KH}_{2} \mathrm{PO}_{4}(10 \mathrm{mM})$ increased the death-rate of N-limited bacteria but the lethal effect was not due to phosphate because $\mathrm{KCl}(10 \mathrm{~mm})$ had a similar effect (Table 2).

Table 3. Effect of various substances on the death-rates of starved, P-limited Aerobacter aerogenes

Bacteria grown in $\mathrm{P}$-limiting medium (dilution rate, $0 \cdot 37 / \mathrm{hr}$ ) were treated as in Table 2. Pairs of viability values refer to averages of duplicate tests on different days.

\begin{tabular}{|c|c|c|c|}
\hline & & & \\
\hline & & & $\begin{array}{r}20 \\
(\%)\end{array}$ \\
\hline Diluent & Additives & 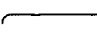 & 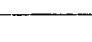 \\
\hline Saline tris & $\begin{array}{l}\text { Nil } \\
\text { EDTA }(0 \cdot 3 \mathrm{mM}) \\
\text { EDTA }(0.3 \mathrm{mM})+\mathrm{KH}_{2} \mathrm{PO}_{4}(10 \mathrm{~mm}) \\
\mathrm{KH}_{2} \mathrm{PO}_{4}(10 \mathrm{mM}) \\
\text { EDTA }(0 \cdot 3 \mathrm{mM})+\mathrm{KCl}(10 \mathrm{mM})\end{array}$ & $\begin{array}{l}97,97 \\
84,92 \\
80,79 \\
98,98 \\
88,79\end{array}$ & $\begin{array}{l}95,96 \\
51,68 \\
37,23 \\
98,97 \\
38,22\end{array}$ \\
\hline Saline phosphate & $\begin{array}{l}\text { Nil } \\
\text { EDTA (0.3 mM) }\end{array}$ & $\begin{array}{l}96,98 \\
76,51\end{array}$ & $\begin{array}{l}82,90 \\
18,16\end{array}$ \\
\hline Saline phosphate $(\mathrm{Na})^{*}$ & $\begin{array}{l}\text { Nil } \\
\text { EDTA }(0.3 \mathrm{~mm})\end{array}$ & $\begin{array}{l}97,97 \\
81,84\end{array}$ & $\begin{array}{l}94,96 \\
53,64\end{array}$ \\
\hline
\end{tabular}

* Saline phosphate (Na) contained only sodium salts.

\section{Phosphorus-limited bacteria}

A formal repetition of tests described by Postgate \& Hunter (1963 $a, 1964)$, with phosphate-limited bacteria grown at $37^{\circ}$ in batch or chemostat cultures, apparently confirmed their findings. Thus, $\mathrm{KH}_{2} \mathrm{PO}_{4}(10 \mathrm{~mm})$ increased the death-rate of these organisms when they were starved in saline tris containing EDTA at $37^{\circ}$. However, further findings (Table 3) showed that, in our experiments at least, "phosphateaccelerated death' had not occurred. (1) When EDTA was omitted from saline tris, the survival of the bacteria was unaffected by $\mathrm{KH}_{2} \mathrm{PO}_{4}$. (2) In saline phosphate (which contained potassium phosphates) survival was good, but the addition of EDTA increased the death-rate markedly. (3) When the $K$ phosphates in saline phosphate were replaced by $\mathrm{Na}$ phosphates, survival was as good in the presence of EDTA as in saline tris + EDTA. (4) In saline tris + EDTA, $\mathrm{KCl}(10 \mathrm{~mm})$ increased the death-rate of the bacteria to the same extent as $\mathrm{KH}_{2} \mathrm{PO}_{4}(10 \mathrm{~mm})$. Thus, the lethal effect of $\mathrm{KH}_{2} \mathrm{PO}_{4}$ in saline tris + EDTA was not due to phosphate ions but to the combined effect of $\mathbf{K}$ ions and EDTA. Also, 'phosphate-accelerated death' apparently occurred with bacteria that were not growth-limited by phosphate. 
For example, N-limited bacteria growing at $37^{\circ}$ (Table 2) and glycerol-limited bacteria growing at $40^{\circ}$ (supplied by Mr J. R. Hunter) died more rapidly at their growth temperature in saline tris $+\mathrm{KH}_{2} \mathrm{PO}_{4}+$ EDTA than in saline tris + EDTA. In the absence of EDTA, these organisms survived well in saline tris $+\mathrm{KH}_{2} \mathrm{PO}_{4}$.

\section{Sulphur-limited bacteria}

When sulphate-limited bacteria were grown with glycerol as carbon source and starved at bacterial concentrations equiv. 10-300 $\mu \mathrm{g}$. dry wt. $/ \mathrm{ml}$. in saline phosphate ( $\mathrm{pH} 6 \cdot 5$ ) or saline tris $\left(\mathrm{pH} 7 \cdot 1\right.$ ) at $37^{\circ}$ for $7 \mathrm{hr}, \mathrm{Na}_{2} \mathrm{SO}_{4}(10 \mathrm{~mm})$ had no effect on the death-rate. In the presence of glucose or glycerol $(10 \mathrm{~mm})$, the viabilities of populations of these bacterial concentrations after $7 \mathrm{hr}$ were $80-85 \%$ as compared with 96-99\% in saline tris alone. These results are in agreement with those of Postgate \& Hunter $(1963 a, 1964)$.

\section{Carbon-limited bacteria}

Glycerol-limited bacteria. Glycerol (10 mM) accelerated the death of glycerollimited Aerobacter aerogenes starved in aerated saline tris or saline phosphate at $37^{\circ}$, but with populations equiv. 8-10 $\mu \mathrm{g}$. bacterial dry wt./ml. the effect was considerably less than that found by Postgate \& Hunter $(1963 a, 1964)$. Tests were therefore

Table 4. Influence of bacterial concentration on the death-rate of Aerobacter aerogenes in the presence of glycerol

\begin{tabular}{|c|c|c|c|c|c|}
\hline & \multirow[b]{3}{*}{$\begin{array}{l}\text { Dry wt. } \\
\text { bacteria } \\
(\mu \mathrm{g} . / \mathrm{ml} .)\end{array}$} & \multicolumn{2}{|c|}{ Colony counts } & \multicolumn{2}{|c|}{ Slide culture } \\
\hline & & \multicolumn{4}{|c|}{ Time (min.) } \\
\hline No lotorim & & \multicolumn{4}{|c|}{$\%$ viability } \\
\hline $2 \cdot 8 \times 10^{7}$ & $8 \cdot 4$ & 74 & 73 & 61 & 58 \\
\hline $1.2 \times 10^{8}$ & $33 \cdot 6$ & 59 & 17 & 46 & $<1$ \\
\hline $5.5 \times 10^{8}$ & 168 & $<1$ & $<1$ & $<1$ & $<1$ \\
\hline $5.5 \times 10^{9}$ & 1680 & $100^{*}$ & $100 *$ & 91 & 90 \\
\hline
\end{tabular}

repeated at $40^{\circ}$ with $A$. aerogenes growing at $40^{\circ}$ (supplied by Mr J. R. Hunter). In saline phosphate, glycerol accelerated death to a greater extent than with bacteria grown and starved at $37^{\circ}$ but the effect was still less than that observed by Postgate \& Hunter; in saline tris + EDTA, glycerol had a marginal effect. This difference of results was probably partly due to the difference in bacterial concentrations routinely used in the tests by Postgate \& Hunter (equiv. $20 \mu \mathrm{g}$. dry wt./ml.) and ourselves (equiv. 8-10 $\mu \mathrm{g}$. dry wt./ml.); between equiv. 8 and about $800 \mu \mathrm{g}$. bacterial dry wt./ml., glycerol-accelerated death increased (not decreased as reported by Postgate \& Hunter, 1964) with bacterial concentration (Fig. 1). With denser populations (above equiv. $1000 \mu \mathrm{g}$. dry wt. bacteria/ml.), substrate utilization produced sufficient acid to change significantly the $\mathrm{pH}$ value of saline 
phosphate. The $\mathrm{pH}$ value of dense suspensions of bacteria was maintained by using a modified saline phosphate $(0.03 \mathrm{M}-\mathrm{NaCl}$ and $0.06 \mathrm{M}$-phosphate, $\mathrm{pH} \mathrm{6.5)}$ or by adding dilute $\mathrm{NaOH}$ at intervals to suspensions in normal saline phosphate. Under these conditions the death-rate in the presence of glycerol decreased with increasing bacterial concentration above equiv. about $800 \mu \mathrm{g}$. dry wt./ml. The influence of bacterial concentration on glycerol-accelerated death was also seen when viabilities were determined by colony counts as well as slide culture (Table 4). The phenomenon was seen with two different samples of A.R. glycerol and a third sample obtained from one of these by distillation under reduced pressure. Changing the concentration of glycerol from 10 to $100 \mathrm{~mm}$ in the tests also had no effect on the death-rates, so that it can be assumed that the results were not due to the use of impure glycerol.

Bacteria-free filtrates from suspensions (equiv. 15, 150 and $1500 \mu \mathrm{g}$. dry wt. bacteria/ml.) incubated in the presence of glycerol had a lethal effect on fresh

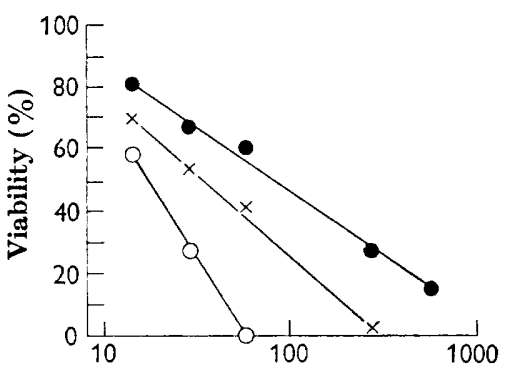

Bacterial dry wt. ( $\mu \mathrm{g} \cdot / \mathrm{ml}$. suspension)

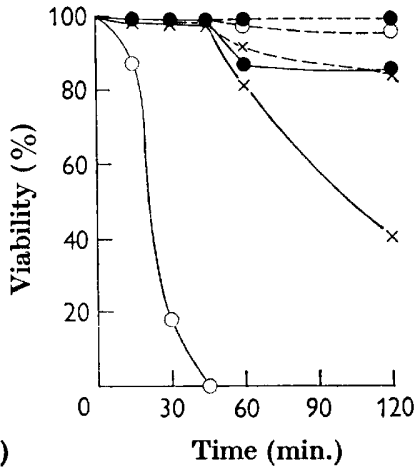

Fig. 2

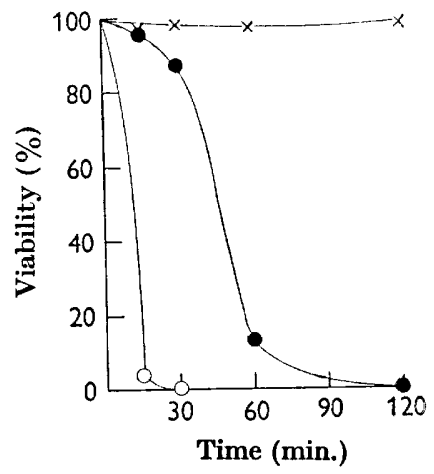

Fig. 3

Fig. 1. Influence of bacterial concentration on the death-rate of Aerobacter aerogenes in the presence of glycerol. Glycerol-limited bacteria from a chemostat (dilution rate, $0 \cdot 42 / \mathrm{hr}$ ) were washed and suspended at concentrations equiv. $14 \cdot 5-5800 \mu \mathrm{g}$. dry wt. bacteria $/ \mathrm{ml}$. in aerated saline phosphate, with and without glycerol $(12.5 \mathrm{~mm})$ at $37^{\circ}$. Viabilities (slide culture) of the suspensions after $1 \mathrm{hr}(0), 2 \mathrm{hr}(\times)$ and $4.5 \mathrm{hr}(O)$. Viabilities of all suspensions without glycerol were 95-98\% and suspensions equiv. 2900 and $5800 \mu \mathrm{g}$. dry wt. bacteria $/ \mathrm{ml}$. with glycerol were 93 and $96 \%$, respectively, after $4.5 \mathrm{hr}$ at $37^{\circ}$. Ordinate scale (viability) is arithmetic and abscissa scale (dry wt.) logarithmic.

Fig. 2. Lethal effect of filtrates from suspensions of Aerobacter aerogenes dying in the presence of glycerol. Glycerol-limited bacteria (as in Fig. 1) at concentrations equiv. 15, 150 and $1500 \mu \mathrm{g}$. dry wt. bacteria/ml. in saline phosphate, with and without glycerol $(10 \mathrm{mM})$, were aerated at $37^{\circ}$ for $90 \mathrm{~min}$. Viabilities were 71,1 and $63 \%$, respectively, in presence of glycerol, and 96,97, 96, respectively, in its absence. Bacteria-free filtrates of the six suspensions were prepared and incubated with fresh bacteria (equiv. 9.5 $\mu \mathrm{g}$. dry wt. $/ \mathrm{ml}$.) in the presence of added glycerol $(10 \mathrm{~mm})$. Viabilities of populations in filtrates from bacterial suspensions equiv. $15(x), 150(O)$ and $1500(0) \mu \mathrm{g}$. dry wt. bacteria/ml. Filtrates from suspensions with glycerol, unbroken lines; without glycerol, broken lines.

Fig. 3. Effect of dialysis on glycerol-accelerated death of Aerobacter aerogenes. Glycerollimited bacteria (as in Fig. 1) equiv. $200 \mu \mathrm{g}$. dry wt./ml. in aerated saline phosphate (5 ml.) + glycerol $(10 \mathrm{~mm})$ were dialysed at $37^{\circ}$ in a cellophan sac against $200 \mathrm{ml}$. diluent + glycerol which was changed every $30 \mathrm{~min}$. A control suspension without glycerol was similarly dialysed against diluent alone, and a third suspension with glycerol was aerated at $37^{\circ}$ without dialysis. Suspension dialysed in the presence of glycerol, dialysed without glycerol, $x$; undialysed suspension with glycerol, $\bigcirc$. 
bacteria; filtrate from the suspension equiv. $150 \mu \mathrm{g}$. dry wt. $/ \mathrm{ml}$. (in which the fastest death-rate occurred) was the most lethal (Fig. 2). Filtrates from similar control suspensions (incubated without glycerol) were non-toxic and filtrate from the strongest bacterial suspension partially protected fresh bacteria from the lethal effect of added glycerol. Dialysis against phosphate saline +glycerol at $37^{\circ}$ of an aerated bacterial suspension (equiv. $200 \mu \mathrm{g}$. dry wt./ml.) containing glycerol markedly decreased the death-rate as compared with that in a similar undialysed suspension (Fig. 3). These experiments show that the population density phenomenon in the presence of glycerol was due to the formation of both toxic and protective substances by the bacteria; the toxic substance diffused through the cellophan in dialysis.

Table 5. Effect of magnesium on glycerol-accelerated death and the toxicity of filtrates from suspensions of Aerobacter aerogenes dying in the presence of glycerol

Bacteria grown in glycerol-limiting medium (dilution rate, $0 \cdot 41 / \mathrm{hr}$ ) were washed and suspended to equiv. $16 \mu \mathrm{g}$. dry wt. bacteria/ml. in saline phosphate $(\mathrm{pH} \mathrm{6.5})$ and in bacteria-free filtrate (of a suspension equiv. $160 \mu \mathrm{g}$. dry wt. bacteria $/ \mathrm{ml}$. +glycerol $(10 \mathrm{~mm})$ aerated at $37^{\circ}$ for $2 \mathrm{hr}$; viability $\left.<1 \%\right)+$ glycerol $(10 \mathrm{~mm})$, with and without $\mathrm{Mg}^{2+}(\mathrm{mm})$. Viabilities (slide culture) were determined at intervals.

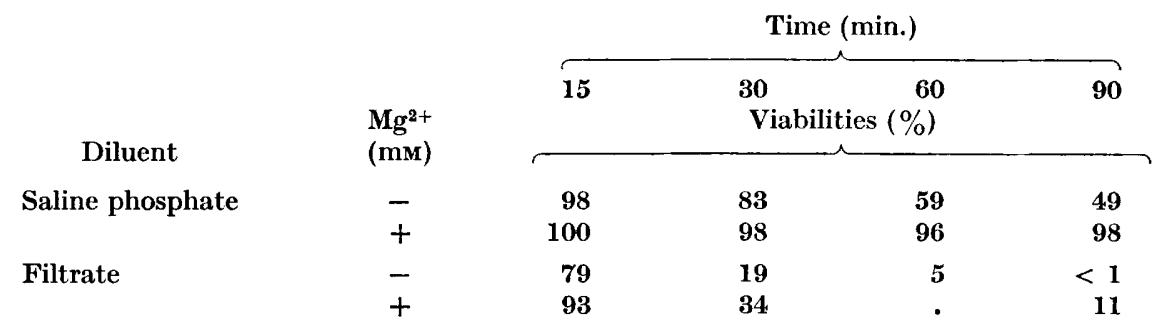

Table 6. Effect of rate of bacterial oxidation of glycerol on glycerol-accelerated death

Aerobacter aerogenes grown in defined C-limiting medium in batch or continuous cultures, washed and suspended in saline phosphate (pH 6.5); $Q_{\mathrm{O}_{2}}$ (glycerol) values were determined in the Warburg apparatus at $37^{\circ}$. Suspensions equiv. 10-800 $\mu \mathrm{g}$. dry wt. bacteria $/ \mathrm{ml}$. were aerated at $37^{\circ}$ with glycerol $(20 \mathrm{~mm})$ and the viabilities (slide culture) determined after $4 \mathrm{hr}$.

Culture conditions

Mannitol-limiting medium in shaken flasks

Mannitol-limiting medium with $0.02 \%(w / v)$ glycerol in chemostat

Glycerol-limiting medium in chemostat
Dry wt. bacteria $(\mu \mathrm{g} . / \mathrm{ml}$.)

$\begin{array}{cccc}\overbrace{10} & \begin{array}{c}200 \\ \text { Viability }\end{array} & \begin{array}{c}400 \\ \text { after }\end{array} & 4 \mathrm{hr} \\ 99 & 99 & 99 & 99 \\ 84 & 61 & 49 & 84 \\ 28 & <1 & <1 & 1\end{array}$

As found by Postgate \& Hunter (1964), $\mathrm{Mg}^{2+}$ abolished glycerol-accelerated death; $\mathrm{Mg}^{2+}$ had less effect on the toxicity of bacteria-free filtrates from suspensions dying in the presence of glycerol (Table 5). 
Glycerol-accelerated death also depended on the rate at which glycerol was oxidized by the bacteria. Table 6 compares the death-rates of similar concentrations of three batches of bacteria, with different $Q_{\mathrm{O}_{2}}$ (glycerol) values, in saline phosphate + glycerol. Bacteria with the highest $Q_{\mathrm{o}_{2}}$ value died at the fastest rate.

Glucose and mannitol also accelerated the death of starved glycerol-limited bacteria but, up to equiv. $800 \mu \mathrm{g}$. dry wt. bacteria/ml., population density had little effect on the death-rate; for example, the viabilities of suspensions containing equiv. 10, 200, 400 and $800 \mu \mathrm{g}$. dry wt. bacteria/ml. with glucose $(20 \mathrm{~mm})$ after $280 \mathrm{~min}$. at $37^{\circ}$ were $46,42,47$ and $50 \%$, respectively. Malate, pyruvate, succinate, citrate and oxalacetate had small effects, compared with glycerol, on the death-rate (Table 7). $\alpha$-Ketoglutarate had no effect although Postgate \& Hunter (1964) found that this keto acid accelerated the death of their bacteria.

\section{Table 7. Effect of metabolic intermediates on the death-rate of starved} Aerobacter aerogenes

Bacteria as in Table 4 were starved at concentrations equiv. 20 and $200 \mu \mathrm{g}$. dry wt. bacteria/ml. in aerated phosphate saline ( $\mathrm{pH} \mathrm{6.5)}$ containing addition (10 mM) at $37^{\circ}$. Viabilities were determined after $120 \mathrm{~min}$. (slide culture).

$\begin{array}{llr}\text { Addition to diluent } & \overbrace{20}^{200} \\ \text { Glycerol } & \mathbf{3 8} & \mathbf{2 0} \\ \alpha \text {-Ketoglutarate } & \mathbf{9 7} & 95 \\ \text { Citrate } & \mathbf{7 9} & \mathbf{9 9} \\ \text { Malate } & \mathbf{9 0} & \mathbf{8 8} \\ \text { Succinate } & \mathbf{8 8} & \mathbf{8 7} \\ \text { Oxaloacetate } & \mathbf{9 0} & \mathbf{9 4} \\ \text { Pyruvate } & \mathbf{5 2} & \mathbf{9 0}\end{array}$

Table 8. Influence of bacterial concentration on the death-rate of Aerobacter aerogenes in the presence of mannitol

Mannitol-limited bacteria from a chemostat (dilution rate $0 \cdot 44 / \mathrm{hr}$ ) were washed and suspended at equiv. 5-800 $\mu \mathrm{g}$. dry wt. bacteria/ml. in aerated phosphate saline (pH 6.5) + mannitol (10 mM) at $37^{\circ}$. Viabilities (slide culture) were determined at intervals.

\begin{tabular}{|c|c|c|c|c|}
\hline \multirow[b]{2}{*}{$\begin{array}{l}\text { Dry wt. bacteria } \\
(\mu \mathrm{g} . / \mathrm{ml} .)\end{array}$} & \multicolumn{4}{|c|}{ Time (hr) } \\
\hline & 1 & 2 & $\begin{array}{r}4 \\
\%)\end{array}$ & 6 \\
\hline $\boldsymbol{5}$ & 55 & 45 & 53 & 49 \\
\hline 100 & 66 & $\mathbf{5 9}$ & 60 & 56 \\
\hline 400 & 63 & 58 & 53 & 52 \\
\hline 800 & 85 & 69 & 57 & 50 \\
\hline
\end{tabular}

Mannitol-limited bacteria. Glucose, mannitol, and, to a smaller extent, galactose and ribose, increased the death-rate of starved mannitol-limited Aerobacter aerogenes. Glycerol had no effect on bacteria with a low $Q_{\mathrm{O}_{2}}$ (glycerol) value (Table 6). The effect of bacterial concentration (equiv. 5-800 $\mu \mathrm{g}$. dry wt./ml.) on mannitol- and glucose-accelerated death of these bacteria was not very great (Table 8). The survival of fresh bacteria in filtrates from populations of different concentrations 
dying after $6 \mathrm{hr}$ in the presence of mannitol varied; viabilities of bacteria (equiv. $10 \mu \mathrm{g}$. dry wt. $/ \mathrm{ml}$.) after $2 \mathrm{hr}$ at $37^{\circ}$ in aerated phosphate saline, phosphate saline + mannitol (10 mM) and filtrates from suspensions equiv. 5, 100, 400 and $800 \mu \mathrm{g}$. dry wt. bacteria/ml. were $92 \cdot 5,55,62 \cdot 5,41 \cdot 2,5 \cdot 6$ and $36 \cdot 2 \%$, respectively.

Galactose- and ribose-limited bacteria. The effects of carbon substrates on the viability of suspensions equiv. $10 \mu \mathrm{g}$. dry wt. galactose- or ribose-limited bacteria/ $\mathrm{ml}$. starved in phosphate saline at $\mathbf{3 7 ^ { \circ }}$ are shown in Table 9 . Substrates other than those which limited growth affected the death-rates, but glycerol, which was oxidized at a slow rate $\left(Q_{0_{2}}, 17-24\right)$, had little effect.

Table 9. Effect of carbon substrates on the death-rates of starved galactose- and ribose-limited Aerobacter aerogenes

\begin{tabular}{|c|c|c|c|c|c|c|}
\hline \multirow[b]{2}{*}{$\begin{array}{l}\text { Growth-limiting } \\
\text { substrate }\end{array}$} & \multirow[b]{2}{*}{$\begin{array}{c}\text { Suspension } \\
\text { substrates } \\
(10 \mathrm{~mm})\end{array}$} & \multirow[b]{2}{*}{$\begin{array}{l}\text { Bacterial } \\
Q_{\mathrm{O}_{2}} \text { with } \\
\text { substrate }\end{array}$} & \multicolumn{4}{|c|}{ Time (hr) } \\
\hline & & & \multicolumn{4}{|c|}{ Viability (\%) } \\
\hline \multirow[t]{4}{*}{ Galactose } & Nil & - & 98 & 98 & 95 & 94 \\
\hline & Galactose & 210 & 92 & 85 & 30 & 29 \\
\hline & Glucose & 197 & 93 & 90 & 59 & 47 \\
\hline & Glycerol & 24 & 96 & 98 & 92 & 80 \\
\hline \multirow[t]{5}{*}{ Ribose } & Nil & - & 100 & 97 & 94 & 89 \\
\hline & Ribose & 230 & 96 & 92 & 61 & 38 \\
\hline & Galactose & 89 & 96 & 92 & 65 & 35 \\
\hline & Glucose & 144 & 93 & 90 & 69 & 48 \\
\hline & Glycerol & 17 & 98 & 98 & 99 & 90 \\
\hline
\end{tabular}

\section{Biochemical changes occurring in suspensions of Aerobacter aerogenes starved in the presences of carbon substrates}

Filtrates from suspensions of C-limited bacteria dying in the presence of glucose, mannitol or glycerol were yellow; they absorbed in the ultraviolet (u.v.) region strongly and, as found by Postgate \& Hunter (1964) in the case of glycerol-accelerated death, these filtrates contained material with a maximum absorption at about 210-240 $\mathrm{m} \mu$. Keto acids determined by the method of Friedmann \& Haugen (1943) were present in filtrates from suspensions of bacteria incubated with mannitol or glycerol; paper chromatographic examination (El Hawary \& Thompson, 1953) showed that these were mainly accounted for as $\alpha$-ketoglutaric acid. The presence of this keto acid was confirmed spectrophotometrically with glutamic acid dehydrogenase. Comparison of the u.v. absorption of $\alpha$-ketoglutarate and filtrates (Fig. 4) suggests that the strong absorption of the filtrates at $210-240 \mathrm{~m} \mu$ was due to keto acids. However, the toxicity of filtrates from organisms dying in the presence of substrate was not due to $\alpha$-ketoglurate because this keto acid had no effect on the death-rate of starved glycerol- (Table 7) or mannitol-limited bacteria, nor did it increase the lethal effect of glycerol on glycerol-limited bacteria. Magnesium abolished substrate-accelerated death but not the release of $\alpha$-ketoglutarate from mannitol-limited bacteria starved in the presence of mannitol, and in the presence 
Table 10. RNA degradation in suspensions of Aerobacter aerogenes starved in the presence of carbon substrates

Mannitol-limited bacteria (as in Table 8) were starved at concentration equiv. $500 \mu \mathrm{g}$. dry wt. bacteria $/ \mathrm{ml}$.) in aerated saline phosphate (pH 6.5), with and without substrates $(25 \mathrm{~mm})$ at $37^{\circ}$. Samples removed at intervals were assayed for viability and RNA.

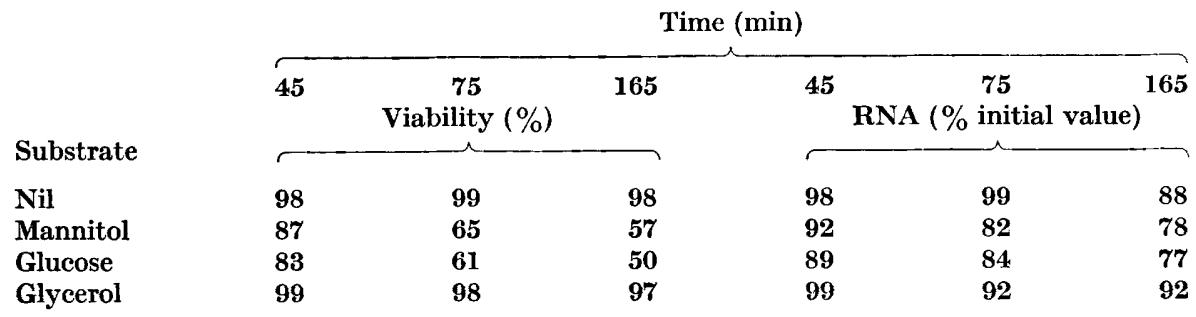

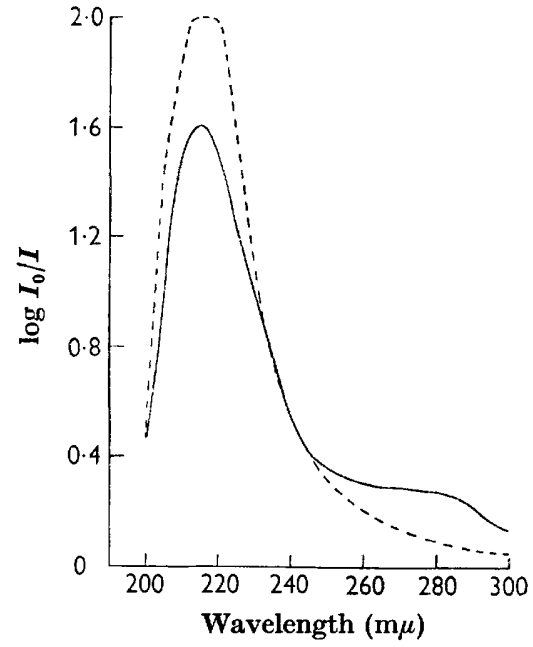

Fig. 4

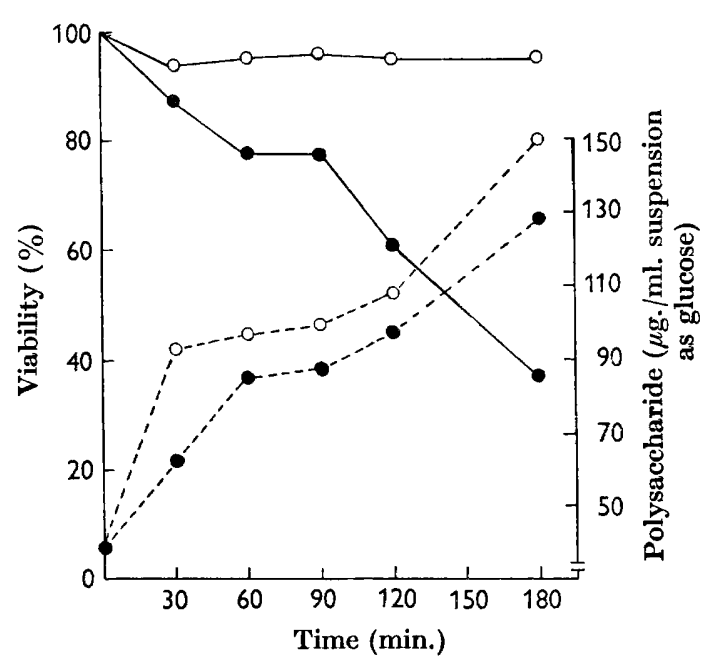

Fig. 5

Fig. 4. Comparison of the u.v.-absorption of $\alpha$-ketoglutarate, and filtrate from Aerobacter aerogenes dying in the presence of glycerol. Cell-free filtrate was prepared from a suspension equiv. $500 \mu \mathrm{g}$. dry wt. bacteria $/ \mathrm{ml}$. saline phosphate + glycerol $(10 \mathrm{~mm})$ which had been aerated at $37^{\circ}$ for $3 \mathrm{hr}$ and contained $242 \mu \mathrm{g}$. keto acid as $\alpha$-ketoglutaric acid $/ \mathrm{ml}$. Filtrate diluted $1 / 3$ in saline phosphate (unbroken line); $\alpha$-ketoglutarate (mM) in saline phosphate (broken line).

Fig. 5. Effect of magnesium on the death-rate and polysaccharide synthesis in Aerobacter aerogenes starved in the presence of mannitol. Mannitol-limited bacteria from a chemostat (dilution, $0.4 / \mathrm{hr}$ ) were washed and starved at concentration (equiv. $1000 \mu \mathrm{g}$. dry wt. bacteria/ml.) in aerated saline phosphate (pH 6.5) + glycerol (25 mM), with and without $\mathrm{Mg}^{2+}(\mathrm{mM})$, at $37^{\circ}$. At intervals samples $(2 \mathrm{ml}$.) were centrifuged and the bacteria resuspended in water $(1.5 \mathrm{ml}$.) for polysaccharide determinations. Viability (slide culture), unbroken lines; polysaccharide $(\mu \mathrm{g} . / \mathrm{ml}$.$) , broken lines. Suspension with$ $\mathrm{Mg}^{2+}, \mathrm{O}$; without $\mathrm{Mg}^{2+}$,

of $\mathrm{Mg}^{2+}$ the synthesis of reserve polysaccharide was marginally increased (Fig. 5). In the absence of added magnesium, the rate of RNA degradation in these bacteria in the presence of mannitol was significantly greater than in similar bacteria starved in phosphate saline, with or without glycerol (Table 10). 


\section{DISCUSSION}

The present results do not support the view of Postgate \& Hunter (1964) that 'substrate-accelerated death' is ubiquitous; the results restrict the phenomenon to the lethal effect of carbon energy sources metabolized by Aerobacter aerogenes in the absence of added magnesium and other nutrients. Differences in the polysaccharide content of the bacteria, and/or the growth and starvation conditions, may account for our failure to observe ammonium-accelerated death of ammoniumlimited bacteria. But it is evident that the phenomenon is less general than was previously supposed. The lethal effect of potassium phosphate on phosphatelimited bacteria starved in the presence of EDTA is confirmed but the previous interpretation of this result as 'phosphate-accelerated death' is shown to be incorrect.

Carbon substrate-accelerated death of Aerobacter aerogenes is confirmed but a specific lethal effect of the growth-limiting carbon source was not evident, although, where metabolic pathways for a particular substrate (e.g. glycerol) involved induced enzyme formation, the growth-limiting substrate might have a greater effect than other substrates. Glucose increased the death-rate of starved bacteria irrespective of the growth-limiting substrate. To some extent this result was anticipated since it had been shown previously that this substrate accelerated the death of $\boldsymbol{A}$. aerogenes grown in a complex medium (Strange et al. 1961). Glycerolaccelerated death of bacteria fully adapted to metabolize glycerol differed from glucose- or mannitol-accelerated death with respect to the influence of the concentration of bacteria on the lethal effect of the substrate. The effect with glycerol, where below a certain bacterial concentration the death-rate increased with the concentration, is due to the production of a product(s) from glycerol which must reach a threshold concentration in the suspending fluid before toxicity is evident. This product has not been identified and it is not possible to say whether the protective effect of bacterial concentration above the critical value is due to restricted synthesis or utilization of the product, or to the neutralizing effect of other substances released from the bacteria. Magnesium abolished glycerolaccelerated death, irrespective of population density, but only marginally decreased the lethal effect of filtrate from bacteria dying in the presence of glycerol. This suggests that magnesium prevents accumulation of the toxic product, either by inhibiting its synthesis or by stimulating its utilization. Although the influence of bacterial concentration on mannitol- (or glucose-) and glycerol-accelerated death was different, the different effects of filtrates from different concentrations of bacteria dying in the presence of mannitol on the death-rate of fresh bacteria suggests that, here too, toxic and protective factors were involved. The present findings do not provide an explanation of the mechanism of substrate-accelerated death but evidence that the metabolism of glycerol, and possibly of other carbon substrates, in the absence of other nutrients and/or magnesium, leads to an accumulation of toxic products which account for perhaps all of the lethal effect, may help further investigation. 


\section{REFERENCES}

Ei. Hawary, M. F. S. \& Thompson, R. H. S. (1953). Separation and estimation of blood keto acids by paper chromatography. Biochem. J. 53, 340.

Friedmann, T. E. \& Haugen, G. E. (1943). Pyruvic acid. II. The determination of keto acids in blood and urine. J. biol. Chem. 147, 415.

Milditzzer, W. E. (1946). Note on the orcinol reagent. Arch. Biochem. 9, 85.

Postgate, J. R., Crumpton, J. E. \& Hunter, J. R. (1961). The measurement of bacterial viabilities by slide culture. J. gen. Microbiol. 24, 15 .

Postgate, J. R. \& Hunter, J. R. (1962). The survival of starved bacteria. J. gen. Microbiol. 29, 233.

Postgate, J. R. \& Hunter, J. R. (1963a). Acceleration of bacterial death by growth substrates. Nature, Lond. 198, 273.

Postgate, J. R. \& Hunter, J. R. (1963b). The survival of starved bacteria. J. appl. Bact. 26, 295.

Postgate, J. R. \& Hunter, J. R. (1964). Accelerated death of Aerobacter aerogenes starved in the presence of growth-limiting substrates. J. gen. Microbiol. 34, 459.

Strange, R. E., Dark, F. A. \& Ness, A. G. (1961). The survival of stationary phase Aerobacter aerogenes stored in aqueous suspension. J. gen. Microbiol. 25, 61.

Strange, R. E. \& Shon, M. (1964). Effects of thermal stress on viability and ribonucleic acid of Aerobacter aerogenes in aqueous suspension. J. gen. Microbiol. 34, 99.

Trevelyan, W. E. \& Harrison, J. S. (1952). Studies on yeast metabolism. 1. Fractionation and microdetermination of cell carbohydrates. Biochem. J. 50, 298. 